\title{
Responses of Estuarine Infauna to Disturbance. II. Spatial and Temporal Variation of Succession
}

\author{
Roman N. Zajac and Robert B. Whitlatch
}

Department of Marine Sciences and Biological Sciences Group, The University of Connecticut, Marine Research Laboratory, Noank, Connecticut 06340, USA

\begin{abstract}
Infaunal successional patterns in Alewife Cove, a small estuary in southeastern Connecticut, USA, varied significantly seasonally and along the estuarine environmental gradient. Each study site exhibited different patterns of change in species composition and abundance. However, suites of species found during succession did not differ greatly from those found in ambient sediments. Species which exhibited the most variable population changes during succession were numerically dominant tubiculous polychaetes (Streblospio benedicti, Capitella spp., Polydora ligni), and an oligochaete (Peloscolex gabriellae). Other species which exhibited significant activity were the polychaetes Scoloplos fragilis, Hobsonia florida and Nereis virens, the hemichordate Saccoglossus kowaleski, and the amphipods Microdeutopus gryllotalpa and Corophium insidiosum. At certain times, densities of these species exceeded or were equivalent to dominant species densities in ambient sediments and experimental plots. Timing of disturbance greatly influenced succession. Succession after an early spring disturbance was characterized by peak species densities and numbers. Succession following a fall disturbance was abbreviated with few species at low densities, while after a summer disturbance intermediate trends were found. Classification analysis of similarity between ambient and successional community structure indicated that recovery to ambient conditions occurred rapidly in the lower reach (14 to $30 \mathrm{~d}$ ), while successional changes in the middle and upper basins continued at least until the end of the winter. It is apparent that estuarine succession can be quite variable and that re-establishment of community structure may occur over various time scales with no set seral stages. The physical and biological processes appearing to be important determinants of estuarine succession include (1) timing of disturbance, (2) habitat in which the disturbance takes place, (3) reproductive periodicity of infauna, (4) ambient population dynamics which generate the pool of recolonizers, (5) abiotic and biotic factors (e.g. food and space resources that affect the preceding 4 factors).
\end{abstract}

\section{INTRODUCTION}

Succession can be considered as local progression of species invasion and occupancy (sensu Paine and Levin, 1981). It is a fundamental process in ecological systems and has been studied in a number of marine soft-bottom environments following various types and scales of disturbance (see Thistle, 1981 for review; Zajac and Whitlatch, 1982 and references therein). Based on these results, several hypotheses of infaunal succession have been proposed. For example, the portion of a successional sequence during which a species will most likely recolonize and establish a population may be related to its life history characteristics. Species which have r-selected and opportunistic traits will be found during early stages, while species which have less opportunistic and K-selected traits will be found in later stages, i.e. closer to recovery (e.g. Grassle and Grassle, 1974; McCall, 1977; Pearson and Rosenberg, 1978; Rhoads et al., 1978). Predictable changes in other community and species characteristics as infaunal succession progresses have also been proposed (e.g. differences in production/biomass and feeding modes: Rhoads et al., 1978).

Many aspects of ambient (undisturbed) infaunal communities (e.g. species composition and diversity, population abundances, biomass, trophic patterns) are known to be variable in time and space. To what extent is this inherent variability evident in successional processes? In a related study (Zajac and Whitlatch, 1982) we showed that initial responses to disturbance of estuarine infauna varied significantly both seasonally and along the estuarine gradient. Here we examine spatial and temporal variation in later stages of succes- 
sion, and based on these results address the following questions:

(1) To what extent are successional dynamics independent of particular habitat conditions? Within an estuary there will exist spatial and temporal differences in numerous physical and biological factors (e.g. levels of food resources, spawning periods). Will these differences affect succession, or will a characteristic progression occur across habitats and seasons?

(2) How does succession differ from species and community fluctuations in ambient portions of the habitat? This comparison is crucial in order to ascertain what in fact constitutes infaunal succession within an estuary.

(3) What factors and/or mechanisms determine the successional dynamics observed?

\section{MATERIALS AND METHODS}

The study was conducted in Alewife Cove $\left(72^{\circ} 07^{\prime} \mathrm{W}\right.$, $41^{\circ} 21^{\prime} N$ ), located in southeastern Connecticut, USA, adjacent to the Thames River (Fig. 1). The Cove is a small (17 ha), shallow estuary whose tidal exchange is with Long Island Sound. Three shallow subtidal study sites were established: Station I (SI) in the lower reach, Station II (SII) in the middle basin, and Station III (SIII) in the upper basin (Fig. 1). Locations of the study sites correspond to physical and biological divisions of the Cove, which are discussed in Zajac and Whitlatch (1982), as well as details on the experimental plots and sampling procedures.

Data were collected from ambient infaunal communities and in situ succession experiments. Disturbance was simulated by setting out plastic buckets (20 cm height, $0.229 \mathrm{~m}^{2}$ surface area) filled with defaunated sediments (sand and mud). The experimental plots comprised two categories. One treatment, referred to as long-term succession, consisted of plots all deployed at the start of the study and sampled after $14,30,154,303$ and $423 \mathrm{~d}$. The 14 and $30 \mathrm{~d}$ data are the same as June and July 1978 recolonization data given in Zajac and Whitlatch (1982). The other treatment, referred to as short-term succession, consisted of plots that were deployed in summer, fall and spring, and sampled after approximately 4 mo. The $154 \mathrm{~d}$ longterm data was used as the summer/fall short-term sample. These 2 sets of experiments were used to study the later stages of estuarine succession.

The sampling schedule is given in Table 1. Five sets of long-term samples were taken and 3 sets of shortterm samples. The ambient sediments in the areas near the experimental arrays were sampled on each sampling date. Each set of samples included 5 randomly

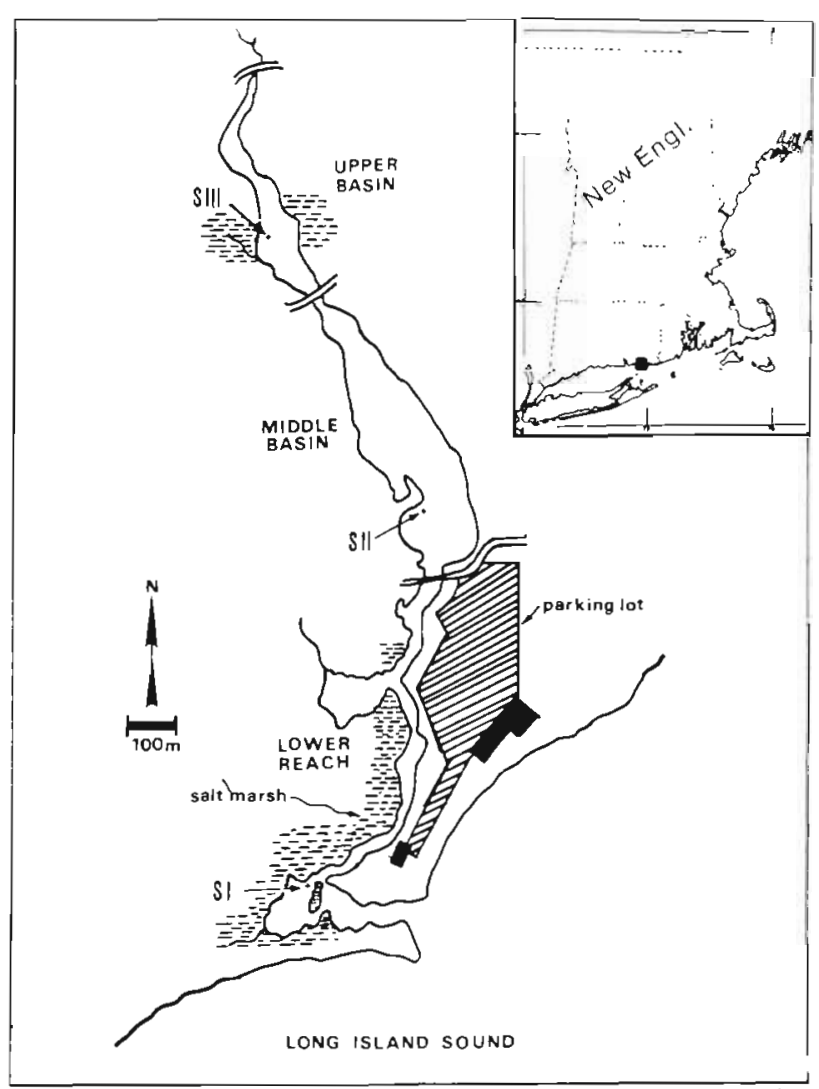

Fig. 1. Location of Alewife Cove in southeastern Connecticut, USA (insert). Arrows indicating $\mathrm{Xs}_{\mathrm{S}}$ denote locations of the 3 study sites (SI, SII, SIII) in the estuary

positioned cores from the ambient sediments and 3 cores from each succession plot. A total of 190 cores were processed. Analytical procedures are given in Zajac and Whitlatch (1982).

\section{RESULTS}

\section{Long-Term Succession Experiments}

The suite of species found in long-term plots was identical to ambient sediments and recolonization plots (Zajac and Whitlatch, 1982), except for the addition of the bivalve Mya arenaria. Changes in species composition during succession are shown in Table 2. Streblospio benedicti, Capitella spp., Peloscolex gabriellae, Polydora ligni, and Scoloplos fragilis usually settled within the first $14 \mathrm{~d}$ after disturbance and remained until termination of the study. At SIII, Hobsonia florida and Eteone heteropoda were also found consistently. Increases in species richness during the spring and summer were due primarily to the settlement of the crustaceans Microdeutopus gryllotalpa, 
Corophium insidiosum, Gammarus mucronatus, and Edotea triloba, and the hemichordate Saccoglossus kowaleski.

Table 1. Sampling schedule of experimental plots in Alewife Cove. Initial deployment of long-term plots was on June 13, 1978. Duration of exposures shown in days (d), months in which long-term samples were taken and seasonal duration of short-term plots shown in parentheses

\begin{tabular}{|ccc|}
\hline $\begin{array}{c}\text { Sampling } \\
\text { deployment }\end{array}$ & Long-term plots & $\begin{array}{c}\text { Short-term } \\
\text { plots }\end{array}$ \\
\hline $6-13-78$ & $\cdot$ & $\cdot$ \\
$6-27-78$ & $14 \mathrm{~d}$ (Jun) \\
$7-13-78$ & $30 \mathrm{~d}$ (Jul) & \\
$11-1-78$ & $154 \mathrm{~d}$ (Nov) & $154 \mathrm{~d}(\mathrm{~s} / \mathrm{f})^{*}$ \\
$3-22-79$ & $303 \mathrm{~d}$ (Mar) & $149 \mathrm{~d}(\mathrm{f} / \mathrm{w})^{\circ}$ \\
$7-20-79$ & $423 \mathrm{~d}$ (Jul) & $112 \mathrm{~d}(\mathrm{sp} / \mathrm{s})$ \\
& \\
fresh plots put into place; s summer; f fall; w winter; \\
sp spring
\end{tabular}

Total Abundance Patterns

Fig. 2 shows fluctuations in total abundance during succession at each of the study sites. Two-way ANOVAs indicated that sampling time (seasonality), estuarine position (station location), and the interaction between them had highly significant effects on total abundance within each sediment type $(p<.001)$.

At SII and SIII initial recolonization was high but decreased throughout the fall. However, at SIII in muds, high initial densities were maintained during this period. Initial recolonization at SI was low relative to SII and SIII, and total abundance remained low through the fall. During the late fall and winter, densities were variable between stations and sediment types. During the following spring and summer, total density increased to peak levels at all stations. This latter stage of succession was the only time when similar changes took place throughout the estuary. While marked fluctuations in total abundance were evident at SII and SIII, SI total abundance increased continuously during the 423-d period.

Densities between sampling periods (stages of community development) at each station were usually significantly different ( $\mathrm{p}<.05$; one-way ANOVAs). At each station, and for each sediment type, between sampling period relationships varied (Zajac, 1981), but significantly higher densities in July 1979 were common to all treatments, except in SII mud plots $(\mathrm{p}<.05$; a posteriori t-tests).

Significant differences in total abundance due to spatial effects were evident during every sampling

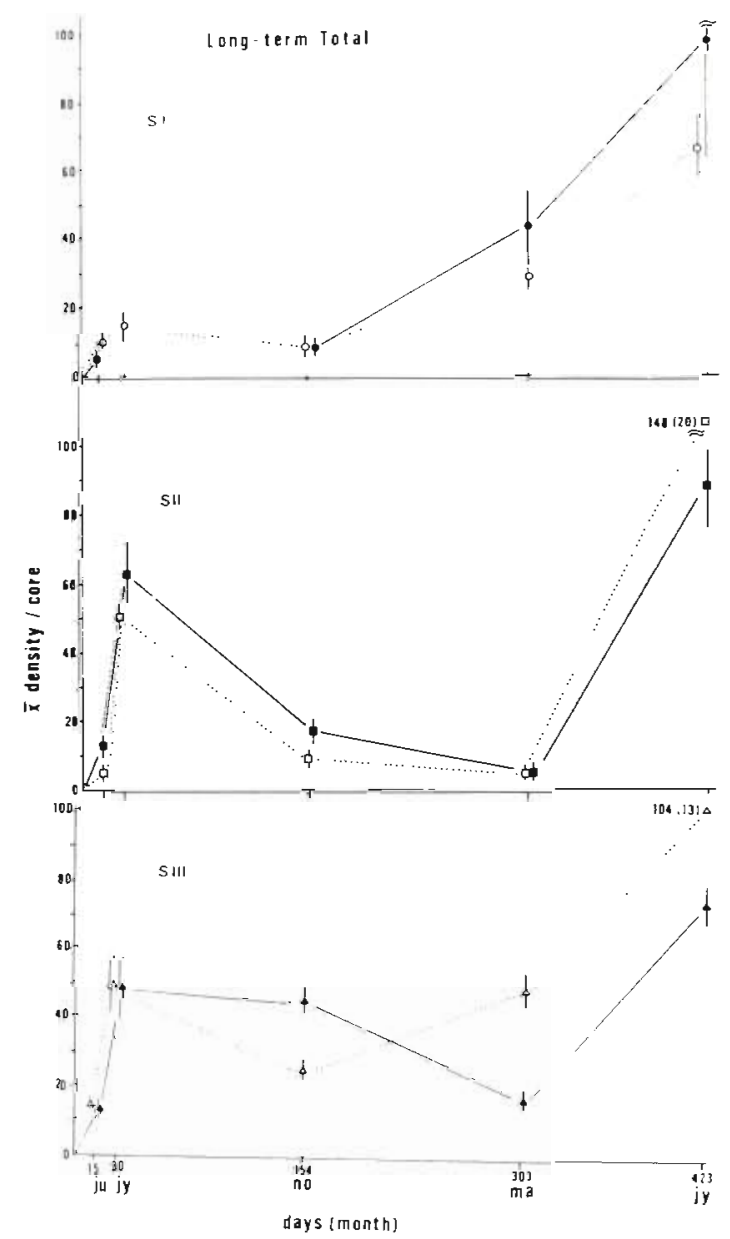

Fig. 2. Long-term total density fluctuations following disturbance in Alewife Cove (mean \pm standard error). For each station, open symbols designate sand plots, closed symbols mud plots. Months corresponding to the times (d) when samples were taken are also given (ju: June, jy: July, no: November, ma: March)

period in sand plots, and after 14, 154 and $303 \mathrm{~d}$ in mud plots ( $p<.05$; one-way ANOVAs). The greatest degree of between-station variability occurred after $303 \mathrm{~d}$ when abundances were significantly different at each station in both sediment types $(\mathrm{p}<.05 ;$ a posteriori $\mathrm{t}-$ tests).

\section{Species Abundance Patterns}

Species population fluctuations during succession are shown in Fig. 3. Density fluctuations of 10 species (Streblospio benedicti, Capitella spp., Peloscolex gabriellae, Polydora ligni, Hobsonia florida, Scoloplos fragilis, Saccoglossus kowaleski, Microdeutopus gryllotalpa and Corophium insidiosum) were significantly different with respect to time, position in the estuary, and the interaction between them ( $p<.05$, two-way ANOVAs). For many of these the differences were 


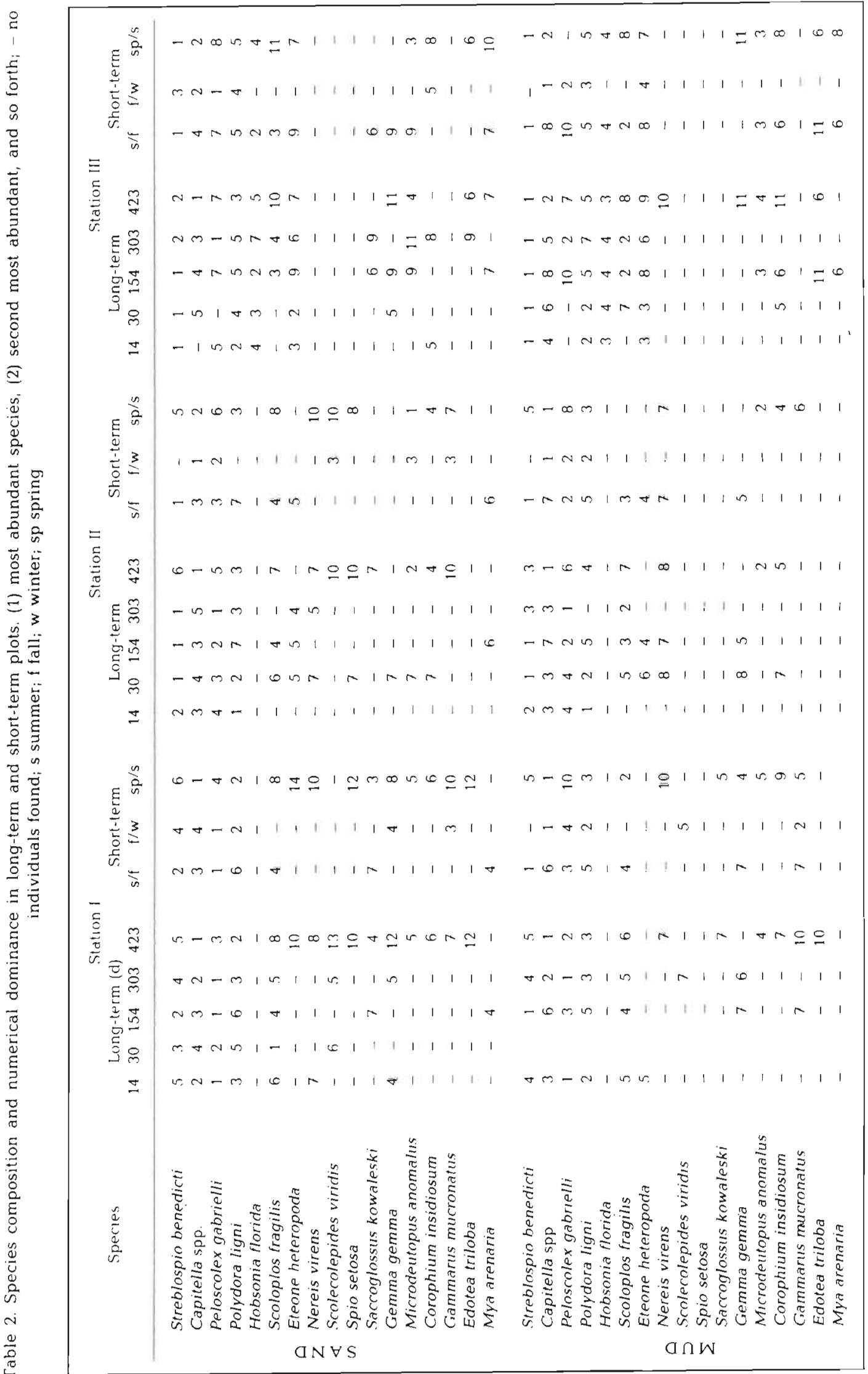



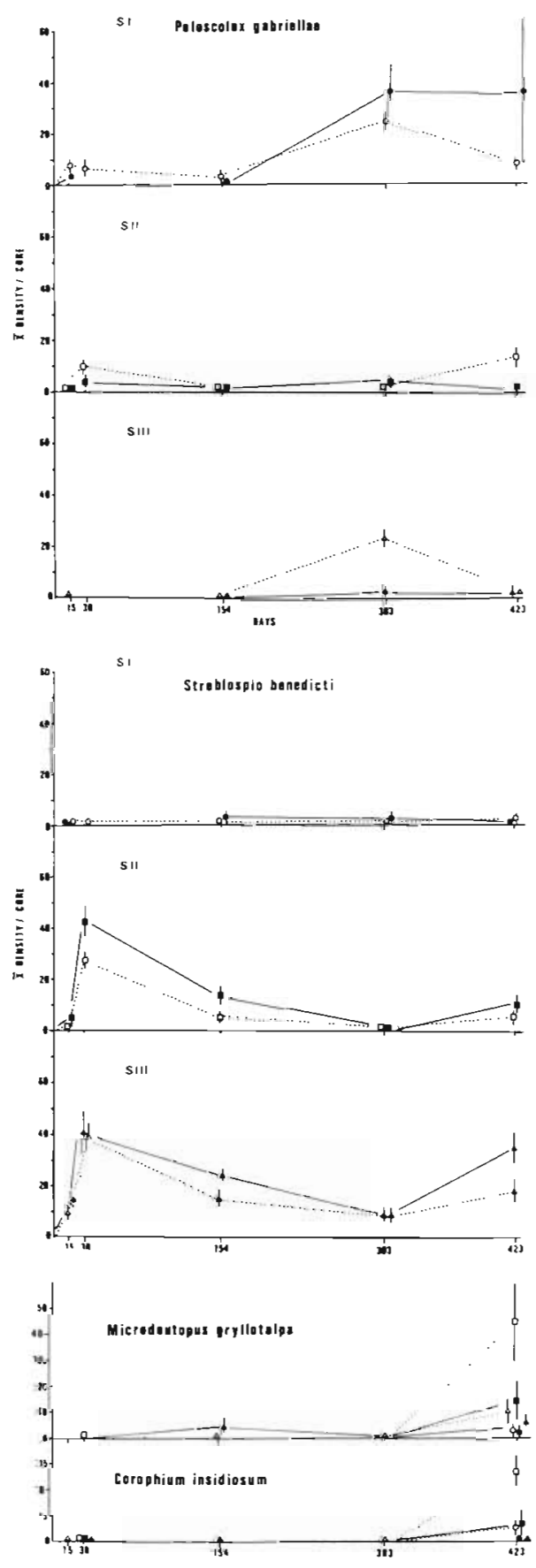

$\Delta$

Fig. 3A. Long-term species density fluctuations following disturbance (mean \pm standard error) Station and sediment symbols as in Fig. 2

Fig. 3B. Data values for all 3 stations are shown on the same graph for these species
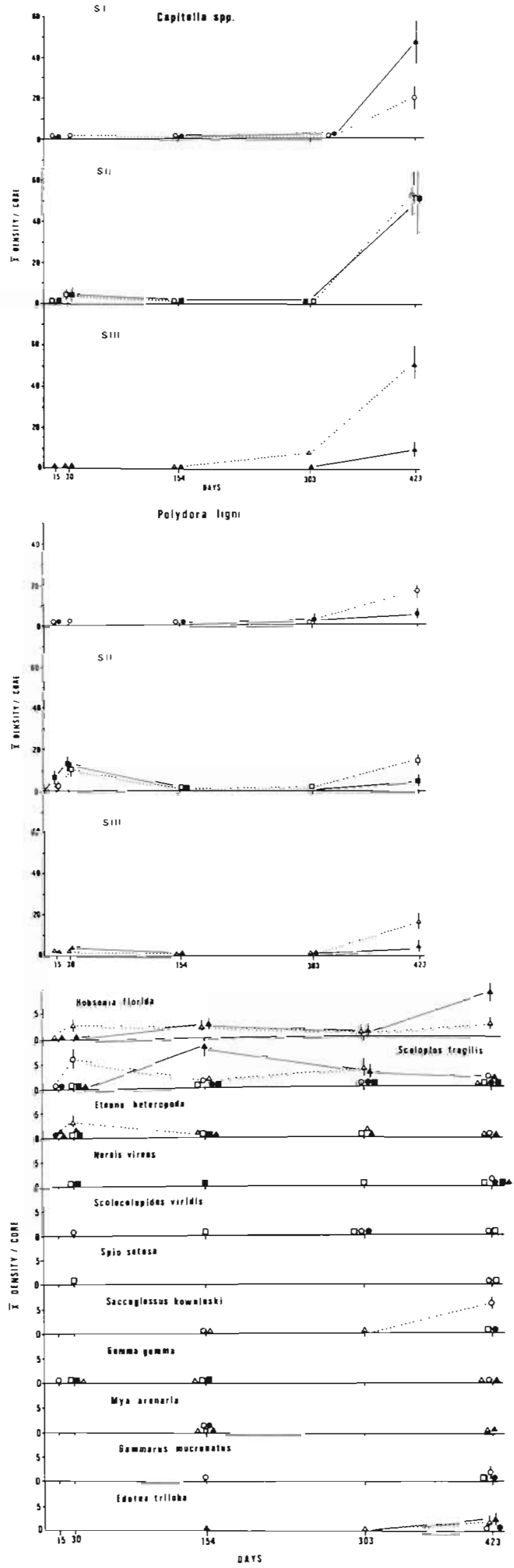
highly significant ( $\mathrm{p}<.001 ;$ Zajac, 1981). Other species were found at lower densities (Fig. 3), and for some, density fluctuations were also statistically significant with respect. to all or some combination of these factors $(\mathrm{p}<.05)$. These included Eteone heteropoda, Nereis virens, Gammarus mucronatus, Edotea triloba, and Mya arenaria. Gemma gemma and Scolecolepidis viridis exhibited no significant differences in density $(p>.05)$, and Spio setosa exhibited only a significant temporal difference in sand plots.

Classification analysis further compared spatial and temporal changes in species populations (Fig. 4). The

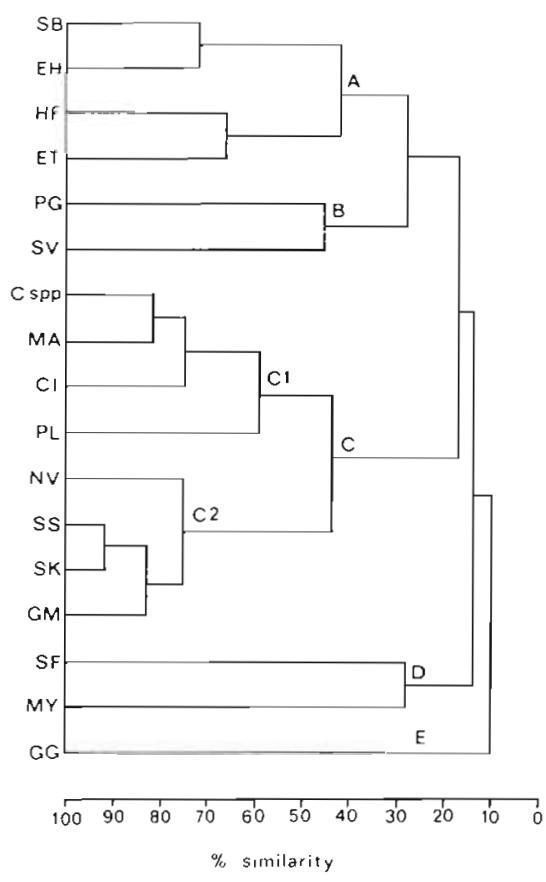

Fig. 4. Similarity dendrogram of species responses during long-term succession. Species are clustered by the similarity of their occurrence and population density at the 3 study sites through time, based on data from all sand and mud core samples taken at $14,30,154,303$ and $423 \mathrm{~d}$. The criteria for combining clusters was average linkange. Groups were determined by visual inspection of the dendrogram. SB StrebIospio benedicti; C spp. Capitella spp.; PG Peloscolex gabriellae; PL Polydora ligni; HF Hobsonia florida; SF Scoloplos fragilis; EH Eteone heteropoda; NV Nereis virens; SV Scolecolepides viridis; SS Spio setosa; SK Saccoglossus kowaleski, GG Gemma gemma; MA Microdeutopus gryllotalpa; CI Corophium insidiosum; GM Gammarus mucronatus; ET Edotea triloba; MY Mya arenaria

overall pattern of clustering indicated that groups formed at highest levels of similarity were comprised of species reaching peak abundances, and/or increased their distributions among the treatments, at similar times and areas of the estuary, during succes sion. Further clustering, at lower levels of similarity, revealed more general station groupings.
Cluster A comprised 4 species which were found at SIII in greatest abundance. Two pairs of species clustered at relatively high levels of similarity; Streblospio benedicti and Eteone heteropoda, which reached peak abundances between 14 and $30 \mathrm{~d}$, and Hobsonia florida and Edotea triloba, which peaked at the termination of the study (Fig. 3). Cluster B comprised 2 species (Peloscolex gabriellae and Scolecolepides viridis) found at quite disparate densities in the long-term plots (Fig. 3), but both were found primarily at SI. Cluster $\mathrm{C}$ comprised 8 species found primarily at SI and/or SII. This cluster formed from 2 subgroups (C1 and $\mathrm{C2}$ ) of 4 species. C1 comprised species which generally increased during the spring and summer 1979 (Capitella spp., Microdeutopus gryllotalpa, Corophium insidiosum and Polydora ligni). Subgroup C2 comprised species found infrequently during the first $303 \mathrm{~d}$ of community development (Nereis virens, Spio setosa, Saccoglossus kowaleski, and Gammarus mucronatus). Saccoglossus kowaleski also exhibited a significant increase in density during this period at SI in sand plots. Scolpolos fragilis and Mya arenaria formed Cluster D. Mya arenaria was found most commonly after $154 \mathrm{~d}$, while Scoloplos fragilis exhibited a significant increase at this time only in mud plots at SIII. At SI it was found in high abundance after $30 \mathrm{~d}$ and its peak density at SIII was attained after $303 \mathrm{~d}$ in sand plots. Gemma gemma (Cluster E) was found at low abundance throughout the study.

\section{Short-Term Succession Experiments}

The long-term succession experiment spanned a period of $423 \mathrm{~d}$ following a disturbance which was initiated in the summer (June 1978). Would the successional pattern be altered if a disturbance occurred in different seasons? To answer this question, another set of experiments (approximately 4 mo periods) were initiated in the fall (fall/winter) and spring (spring/ summer). The 154 -d data from the long-term plots are included as a summer/fall treatment.

Total abundances attained after each 4 mo exposure period are shown in Fig. 5. Recolonization abundances that were found after the initial stages of each exposure period are also included to illustrate comparative change (data from Zajac and Whitlatch, 1982). During the summer/fall period, total abundance increased sharply at SII and SIII, but had declined by November in all treatments. The fall/winter exposure was marked by relatively low and unchanging abundances. The highest densities were found after the spring/summer exposure at each of the study sites. Total densities at the termination of each experiment were significantly different on the basis of exposure period, position in 


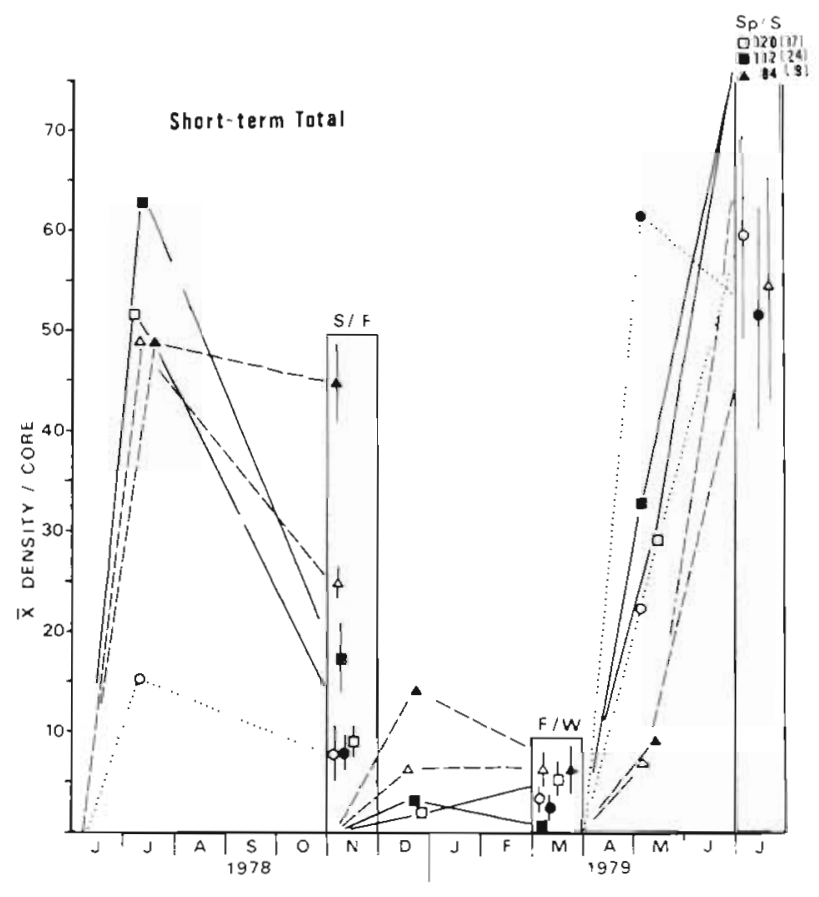

Fig. 5. Short-term total density fluctuations (mean \pm standard error). Densities found after the summer/fall (S/F), fall/winter (F/W) and spring/summer ( $\mathrm{Sp} / \mathrm{S})$ exposure periods are shown within the histograms. Data from recolonization plots (Zajac and Whitlatch, 1982), initiated at the same time as the shortterm plots, are shown to indicate initial responses at the start of an exposure period and direction of density changes to the end of the exposure period. Station and sediment symbols same as in Fig. 2
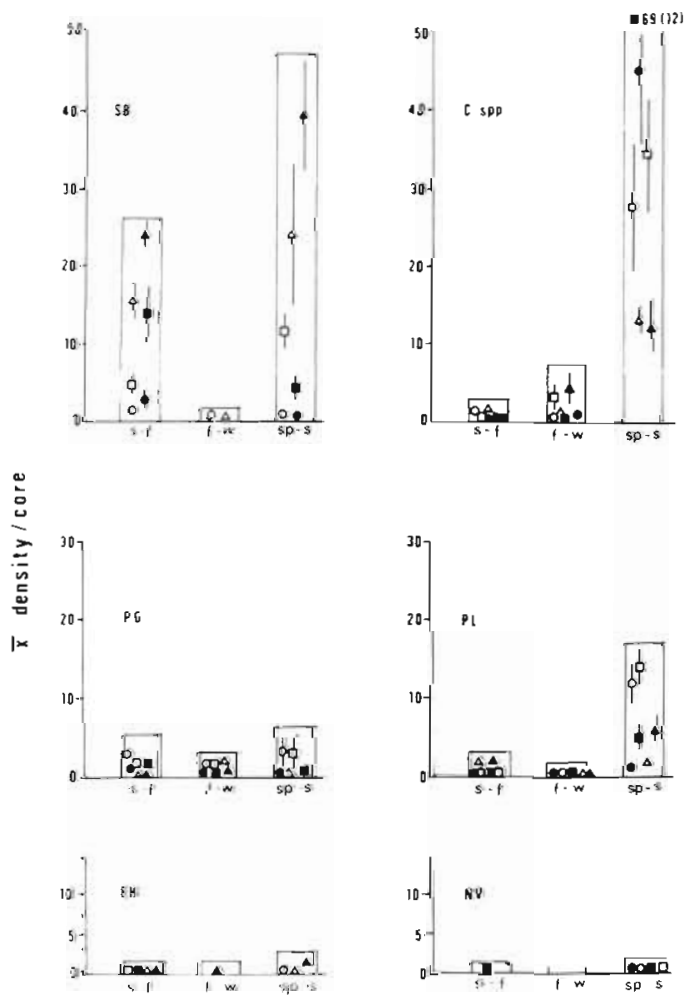

the estuary and the interaction between these two parameters in both sediment types $(p<.001$; two-way ANOVAs).

Significant spatial effects occurred after the summer/ fall period (sand and mud) and after the spring/summer period in sand plots. After the summer/fall, total density at SIII was significantly higher than at SI and SII ( $\mathrm{p}<.05$; a posteriori t-tests). This relationship was found in ambient sediments and recolonization plots sampled in November (Zajac and Whitlatch, 1982). After the spring/summer, densities at SII were significantly higher than at SI and SIII.

In contrast, the timing of disturbance within-stations had a very strong effect on total abundance. In only one case (SIII mud plots between summer/fall and spring/ summer) did different exposure periods yield abundances that were not significantly different $(p<.05$; oneway ANOVAs).

Highest numbers of species were generally found after the spring/summer exposure, while lowest numbers were found after the fall/winter exposure (Table 2). Intermediate species richness was found after the summer/fall period, but in a number of cases these were similar to spring/summer levels. At SIII, the number of species was the same after each of these periods. Streblospio benedicti, Capitella spp., Peloscolex gabriellae and Polydora ligni were found fairly consistently after each exposure period.

Although these 4 dominant species were found consistently, the population densities they attained after
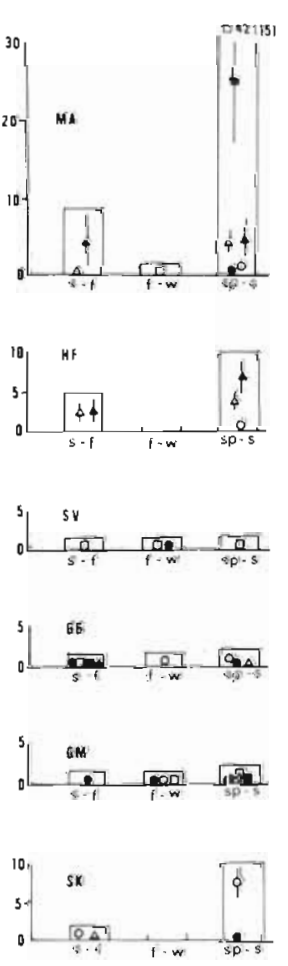
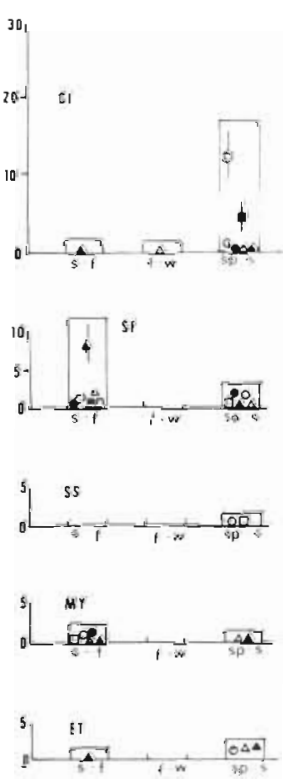

Fig. 6. Short-term species densities found after each exposure period (mean \pm standard error). Station and sediment symbols same as in Fig. 2; species symbols same as in

Fig. 4 
Table 3. Results of one-way ANOVAs testing density differences between long-term and short-term succession plots and ambient sediments (data from Zajac and Whitlatch, 1982). Corresponding a posteriori t-test matrix results shown below ANOVA entries. For ANOVAs: ${ }^{\prime} p<.05 ; \cdots p<.01 ; \cdots p<.001$; NS no significant differences; + no individuals found. For t-tests, a line connecting any treatments indicates no significant differences in density. Long-term results designated by the series: June, July (1978), November, March, July (1979). Short term results designated by: s/f summer/fall; f/w fall/winter; sp/s spring/summer; $\mathrm{s}$ sand $\mathrm{m}_{\text {mudi }}$ a ambient

\begin{tabular}{|c|c|c|c|c|c|c|c|}
\hline \multirow[b]{2}{*}{ Species } & \multicolumn{5}{|c|}{$s / f$} & \multirow[b]{2}{*}{$f / w$} & \multirow[b]{2}{*}{$\mathrm{sp} / \mathrm{s}$} \\
\hline & Jun & Jul & Nov & Mar & Jul & & \\
\hline \multirow[t]{2}{*}{ Streblospio benedicti } & $\cdot$ & $\cdots$ & • & NS & NS & $\cdots$ & NS \\
\hline & $\underline{\mathrm{msa}}$ & $\underline{s m a}$ & $\underline{\mathrm{ms}} \underline{\underline{a}}$ & & & $\underline{s m a}$ & \\
\hline \multirow[t]{2}{*}{ Capitella spp. } & $\cdots$ & - & NS & NS & - & NS & $\cdot$ \\
\hline & $\underline{\operatorname{sm}} \mathbf{a}$ & $\underline{s m a}$ & & & $\underline{\operatorname{sma}}$ & & $\underline{\mathrm{msa}}$ \\
\hline \multirow[t]{2}{*}{ Peloscolex gabrielli } & $\cdots$ & NS & NS & - & NS & - & $\cdots$ \\
\hline & $\underline{s m a}$ & & & $\underline{\mathrm{sma}}$ & & $\underline{\text { mas }}$ & $\underline{\text { sam }}$ \\
\hline \multirow[t]{2}{*}{ Polydora ligni } & $\cdots$ & NS & - & NS & $\cdots$ & NS & - \\
\hline & $\underline{s m a}$ & & $\underline{\mathrm{ms}} \underline{\underline{a}}$ & & sam & & sam \\
\hline Hobsonia florida & NS & NS & NS & NS & NS & + & NS \\
\hline \multirow[t]{2}{*}{ Scoloplos fragilis } & $\cdots$ & NS & - & NS & NS & $\cdots$ & - \\
\hline & $\underline{\operatorname{sm}} a$ & & $\underline{\mathrm{ms}} \underline{\underline{a}}$ & & & $\underline{s m a}$ & $\underline{s m a}$ \\
\hline \multirow[t]{2}{*}{ Eteone heteropoda } & NS & $\cdot$ & NS & NS & NS & NS & NS \\
\hline & & $\underline{s m a}$ & & & & & \\
\hline \multirow[t]{2}{*}{ Nereis virens } & $\cdots$ & NS & NS & NS & NS & + & NS \\
\hline & $\underline{\text { sma }}$ & & & & & & \\
\hline Scolecolepides viridis & + & NS & NS & NS & NS & NS & NS \\
\hline Spio setosa & NS & NS & + & + & NS & + & NS \\
\hline \multirow[t]{2}{*}{ Saccoglossus kowaleski } & + & + & - & NS & - & + & NS \\
\hline & & & sima & & $\underline{\operatorname{sam}}$ & & \\
\hline \multirow[t]{2}{*}{ Gemma gemma } & $\cdots$ & $\cdots$ & NS & NS & NS & NS & NS \\
\hline & $\underline{s m a}$ & $\underline{s m a}$ & & & & & \\
\hline \multirow[t]{2}{*}{ Microdeutopus anomalus } & + & NS & NS & NS & $\cdots$ & NS & - \\
\hline & & & & & $\underline{\underline{s m a}}$ & & $\underline{s m a}$ \\
\hline \multirow[t]{2}{*}{ Corophium insidiosum } & NS & NS & NS & NS & $\cdot$ & NS & $\cdot$ \\
\hline & & & & & sam & & $\underline{\underline{s} \mathbf{m a}}$ \\
\hline Edotea triloba & + & NS & NS & NS & NS & + & NS \\
\hline Gammarus mucronatus & + & NS & NS & + & NS & NS & NS \\
\hline \multirow[t]{2}{*}{ Mya arenaria } & + & + & $\cdot$ & + & NS & + & NS \\
\hline & & & $\underline{s m} a$ & & & & \\
\hline \multirow[t]{2}{*}{ Total density } & $\cdots$ & NS & - & NS & $\cdots$ & $\cdots$ & NS \\
\hline & $\underline{s m a}$ & & $\underline{\operatorname{sma}}$ & & $\underline{\underline{s m a}}$ & sma & \\
\hline
\end{tabular}

each exposure period (Fig. 6) were significantly different ( $p<.05$; two-way ANOVAs) except for Peloscolex gabriellae in sand plots, and there were no significant differences in density between stations for Capitella spp. and Peloscolex gabriellae, and Polydora ligni in sand plots. In most cases these species attained significantly higher abundances after the spring/summer exposure $(p<.05)$, while the lowest densities were found after the fall/winter period. Many species which were found at low or moderate abundances, on an overall basis, attained significant population peaks after the spring/summer relative to the other exposure periods. These included Saccoglossus kowaleski, Eteone heteropoda, Nereis virens, Microdeutopus gryllotalpa, Corophium insidiosum and Edoted triloba. Gemma gemma and Gammarus mucronatus densities did not vary significantly between treatments and Scolecolepides viridis and Spio setosa densities varied significantly with respect to only position and exposure period, respectively. 


\section{Sediment Effects and Comparisons to Ambient Dynamics}

Significant differences in total density in the longterm succession treatments, with respect to sediment type and ambient conditions, occurred at $14 \mathrm{~d}$ (ambient levels higher than experimental plots), at $154 \mathrm{~d}$ (experimental densities higher) and at $423 \mathrm{~d}$ (sand plots higher than mud and ambient levels) (Table 3). There were no significant differences at $30 \mathrm{~d}$, when peaks of recolonization and increases in ambient summer densities coincided, and at $303 \mathrm{~d}$, when total abundances in experimental plots and ambient sediments decreased during fall and winter.

The largest differences in total density in the shortterm succession treatments occurred after the fall/ winter exposure. At this time, sand and mud densities were significantly different from one another, and both were lower than ambient levels $(p<.05)$. There were no differences after the spring/summer exposure.

The greatest differences in species densities between long-term plots and ambient sediments were found among numerically dominant species. Fourteen d after disturbance, significant differences were exhibited by each of the four dominants. Densities of Streblospio benedicti (mud plots only) and Polydora ligni were significantly higher, and densities of Peloscolex gabriellae and Capitella spp. were significantly lower relative to ambient levels (Table 3). During the late summer, fall and winter, densities were usually similar to ambient levels. However, Streblospio benedicti and Polydora ligni maintained higher densities in mud plots through the late summer and early fall, whereas densities of Peloscolex gabriellae after the winter were higher than in ambient sediments. After the following spring and summer, only Capitella spp. and Polydora ligni (sand plots) densities differred from ambient levels. In each case experimental plots contained significantly higher densities $(p<.05)$. Responses of the dominants were variable, relative to their ambient population levels, in the short-term treatments also (Table 3).

Differences between sediments and ambient conditions for the other species were usually not statistically significant ( $p>05$ ). However, Scoloplos fragilis exhibited significant differences after all of the timing of disturbance treatments, and Microdeutopus gryllotalpa and Corophium insidiosum were found at higher densities in long-term sand plots after $423 \mathrm{~d}$.

In order to examine the changes in community structure following a disturbance relative to areal and seasonal differences in ambient dynamics, a classification analysis of ambient and long-term samples was performed. Six major clusters were formed primarily on the basis of estuarine position (Fig. 7, Table 4). The groups forming the clusters were comprised of treatments that were most similar on the basis of sediment (sands, muds and ambient sediments) and/or time of sampling.

Cluster $A$ included 4 out of the 5 ambient samples from SI, indicating a general consistency in ambient community structure over time. Peloscolex gabriellae, Streblospio benedicti, Polydora ligni and Capitella spp. were the dominant species in ambient sediments during these times, with Peloscolex gabriellae being the numerical dominant (Zajac and Whitlatch, 1982).

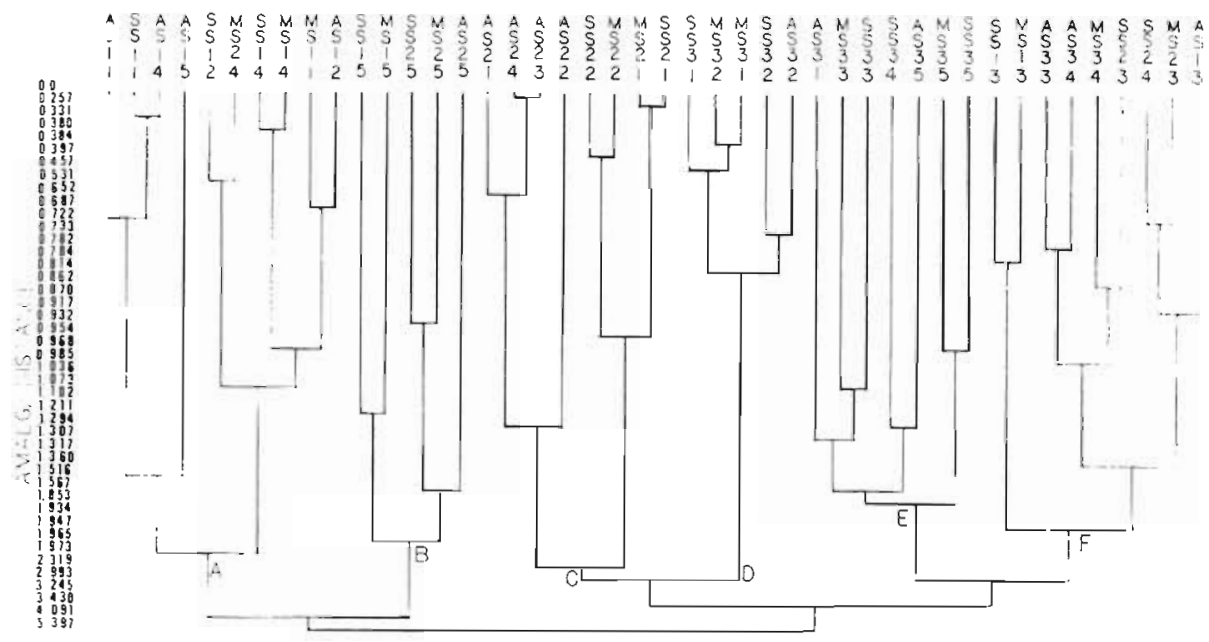

Fig. 7. Similarity dendrogram of long-term succession and ambient treatments (samples). Treatments were clustered (amalgamated) according to the similarity of species composition and abundance. Mean density per core was used for each species. Clusters were combined by a chi-square test of equality algorithm (Dixon and Brown, 1979). Lower amalgamation distances indicate more similarity between treatments. A ambient; S sand; M mud; S1 SI; S2 SII; S3 SIII; 1, 2, 3, 4, 5: June, July 1978, November, March and July 1979 respectively (i.e. 14, 30, 154, 303 and 423 d). For example, AS 11 represents ambient samples at Station I in June 1978 
Table 4. Grouping data for clusters formed in Fig. 7. Treatments included within a cluster designated by A (Ambient), S (Sand) and M (Mud). There is no data from July SI mud plots

\begin{tabular}{|c|c|c|c|c|c|c|}
\hline \multirow[b]{2}{*}{ Cluster } & \multicolumn{6}{|c|}{ Sampling period } \\
\hline & Station(s) & $\begin{array}{l}14 \mathrm{~d} \\
\text { Jun }\end{array}$ & $\begin{array}{c}30 \mathrm{~d} \\
\mathrm{Jul}\end{array}$ & $\begin{array}{l}154 \mathrm{~d} \\
\text { Nov }\end{array}$ & $\begin{array}{c}303 \mathrm{~d} \\
\text { Mar }\end{array}$ & $\begin{array}{c}423 d \\
\text { Jul }\end{array}$ \\
\hline A & SI & $\begin{array}{l}\mathrm{A} \\
\mathrm{S} \\
\mathrm{M}\end{array}$ & $\begin{array}{l}\text { A } \\
S\end{array}$ & - & $\begin{array}{l}\mathrm{A} \\
\mathrm{S} \\
\mathrm{M} \\
\mathrm{M} \text { (SII) }\end{array}$ & A \\
\hline B & SI-SII & - & - & - & - & $\begin{array}{l}\mathrm{A} \quad(\mathrm{SII}) \\
\mathrm{S} \quad(\mathrm{SI}, \mathrm{SII}) \\
\mathrm{M} \text { (SI, SII) }\end{array}$ \\
\hline C & SII & $\begin{array}{l}\mathrm{A} \\
\mathrm{S} \\
\mathrm{M}\end{array}$ & $\begin{array}{l}\mathrm{A} \\
\mathrm{S} \\
\mathrm{M}\end{array}$ & A. & A & - \\
\hline D & SIII & $\begin{array}{c}- \\
\mathrm{S} \\
\mathrm{M}\end{array}$ & $\begin{array}{l}A \\
S \\
M\end{array}$ & - & - & - \\
\hline E & SIII & A & - & $\overline{\mathrm{S}}$ & $\begin{array}{l}- \\
S \\
M\end{array}$ & $\begin{array}{l}\mathrm{A} \\
\mathrm{S} \\
\mathrm{M}\end{array}$ \\
\hline $\mathrm{F}$ & SI-SII-SIII & - & - & $\begin{array}{l}\text { A }(\mathrm{SI}, \mathrm{SIII}) \\
\mathrm{S} \text { (SI, SII) } \\
\mathrm{M}(\mathrm{SI}, \mathrm{SII})\end{array}$ & $\begin{array}{ll}\text { A } & \text { (SIII) } \\
\text { S (SII) } \\
M & \text { (SIII) }\end{array}$ & - \\
\hline
\end{tabular}

The succession treatments included in this group had a similar species dominance structure (Table 2).

Cluster B included both sediment treatments sampled in July 1979 at SI and SII, but only the ambient samples from SII. All these samples were distinguished by increases in density in a number of species, including Capitella spp., Polydora ligni, Microdeutopus gryllotalpa, and Corophium insidiosum.

Sharp increases in total abundance were evident in the June-July 1978 treatments comprising Cluster C, but species dominance structure differed between ambient sediments and long-term treatments. In the ambient sediments, Capitella spp. dominated; this species was found at significantly lower densities in the experimental plots. In the long-term plots, Streblospio benedicti and Polydora ligni were dominants, but their ambient densities were relatively low at this time. No long-term treatments were grouped with the November and March ambient samples found in this cluster. This suggests that community structure in the long-term plots varied significantly from ambient conditions during late summer, fall and winter at SII.

Cluster D was comprised entirely of SIII treatments in a June-July 1978 seasonal grouping, similar to that at SII (Cluster C). Sharp increases in abundance by Streblospio benedicti were evident in each of these treatments.

Cluster E was also comprised of all SIII treatments, but the grouping in this cluster was not as distinct. In July 1979, significant increases in abundance of Streblospio benedicti, Polydora ligni, Hobsonia florida and Edotea triloba were found. The inclusion of November and March experimental treatments most likely reflects the maintenance of high densities by Streblospio benedicti during the late summer and fall (sand and mud), and winter (sand).

Cluster F comprised a variety of November and March treatments from SI, SII and SIII. Streblospio benedicti and Peloscolex gabriellae occurred at relatively high densities at these times and locations.

\section{DISCUSSION}

In Alewife Cove, infaunal succession varied both temporally and spatially. Following a summer disturbance, experimental plots at 3 locations within the estuary exhibited distinct patterns of succession over a period of $423 \mathrm{~d}$. Species composition was similar between sites during most sampling periods, but significant differences in abundance and dominance were evident. A variety of physical and biological factors (e.g. levels of food resources, sedimentation, resuspension, spawning periods) may have affected these patterns (Zajac and Whitlatch, 1982). Therefore, there is no characteristic successional progression that can be 
constructed for the infauna irrespective of time and the estuarine gradient. Estuarine successional dynamics are apparently dependent on particular habitat conditions.

The variability in successional dynamics was similar to that observed in the ambient community (Zajac and Whitlatch, 1982). During several portions of the study period, experimental plots and ambient sediments exhibited similar species composition and densities, but these varied considerably at other times and locations. At SI, ambient and long-term treatments from June, July 1978, November and March were found in the same clusters (Fig. 7). Only the July 1979 treatments varied from this pattern. At SII and SIII, June and July 1978 and 1979, long-term treatments usually clustered with their ambient counterparts, but did not cluster with November and March ambient samples. This overall pattern suggests that SI ambient community structure was re-established fairly soon after the summer disturbance (14 to $30 \mathrm{~d}$ ). Ambient community structure at SII and SIII was also re-established by $30 \mathrm{~d}$, but became dissimilar through the fall and winter. During the following spring and summer, similar community structure was again evident between experimental plots and ambient sediments at SII and SIII. At these 2 study sites changes in community structure as a result of disturbance may have continued until the end of winter, despite a brief period of similarity during the first $30 \mathrm{~d}$. These changes can be considered successional, in contrast to the apparently seasonal changes in SI long-term plots after $30 \mathrm{~d}$.

Species-specific patterns of recovery were also quite variable, especially when both early and late successional stages were considered. For example, densities of Streblospio benedicti were significantly different from ambient levels during the first 3 sampling periods, after which similar densities were found (303 to $423 \mathrm{~d}$; Table 3). However, densities of Streblospio benedicti after shorter exposure periods also did not differ from ambient levels. This was evident in the 112 d spring/summer exposure (Table 3), and after most recolonization experiments, 30 to $60 \mathrm{~d}$ (Zajac and Whitlatch, 1982). Similar patterns of variation in recovery to ambient levels were exhibited by most species examined in the study (Table $3 ;$ Zajac and Whitlatch, 1982).

Short-term succession data, although limited to approximately 4 mo periods, also indicated that species responses and community structure after a disturbance can be significantly altered by the time of its occurrence. After a spring disturbance, community development was characterized by higher species richness, greater areal distribution of species, and high species densities. In contrast, community development after a fall disturbance was abbreviated; fewer species were found and the density of infauna was quite low. The summer/fall development was intermediate, resembling the spring/summer at the outset, but declines in population density were evident as development progressed into the fall. As another example of the relative nature of estuarine succession, plots exposed in the beginning of the spring (112 d; spring/summer treatment) contained very similar species assemblages as plots exposed from the previous summer (423 d), ambient sediments (423 d of observation) and recolonization plots exposed for $44 \mathrm{~d}$ and sampled at the same time (July 1979). In many cases species densities were similar also.

These trends lead to several conclusions about the nature of estuarine infaunal succession and communities. First, recovery of estuarine infaunal communities from a disturbance can occur over various time scales with no set seral stages and the dynamics may be primarily influenced by the timing of the disturbance, and not by the recovery process itself. Seral stages, though ephemeral, probably do occur, and for those that occur very quickly (e.g. in spring and summer) observations on a weekly period may be needed to distinguish them and any species interactions influencing the progression (Whitlatch and Zajac, in preparation). Further, the climax community in Alewife Cove is the ambient community as described in this study (Zajac and Whitlatch, 1982), if ecological climax is defined as the terminal stage (stage parameters include species composition, dominance patterns and density changes) of a seral sequence under prevailing conditions. A climax community is also characterized by fairly stable structure through time (e.g Odum, 1969; Whittaker and Levin, 1977). Infaunal dynamics observed during this study and in the course of ongoing work in Alewife Cove (Whitlatch and Zajac, in preparation) are similar to that previously observed by Welsh et al. (1978), suggesting a general long-term consistency. Boesch et al. (1976) have noted that estuarine infaunal communities poses 'high stability in their resistance to, and resilience from, disturbances'. Not only does the Alewife Cove infauna appear to be stable and resilient, but also persistent through time. The community is dominated by species which have, or could be, characterized as opportunists, and likely would not be found as members of climax communities in other marine soft-bottom environments. This points out that a rescaling of environmental conditions can reposition a species role in the community. Therefore, our concepts of succession must also be rescaled to reflect the changing roles and importance species have in particular environments.

More generally, studies of succession have resulted in a variety of viewpoints and hypotheses concerning the patterns and mechanisms involved as communities 
become re-established following a disturbance (e.g. Drury and Nisbet, 1973; Whittaker and Levin, 1977 and references therein). Based on many of these viewpoints, Connell and Slatyer (1976) have formulated 3 contrasting models of succession: facilitation, tolerance, and inhibition. Briefly, facilitation is based on biotic habitat modification by each group of species that enhances the settlement of subsequent groups. Tolerance mechanisms center on differences in species resource utilization patterns and life histories. Inhibition involves suppression of settlement and/or growth of other species by those already established in the disturbed area. The patterns of infaunal succession found in this and other studies exhibit elements of each of these models. For example, the initial establishment of populations by early colonizing, or opportunistic species, is a component of each model. This trend has been noted in a number of infaunal habitats (Thistle, 1981). Results from some of these studies suggest that this initial phase of opportunists is followed by increasing dominance of relatively less opportunistic species, or species possessing K-selected adaptations (e.g. McCall, 1977; Pearson and Rosenberg, 1978; Rhoads et al., 1978).

In contrast, our results, and data from other studies (Reisch, 1961; Guerin and Masse, 1976; McCall, 1977; Richter and Sarnthien, 1977; Wolff et al., 1977; Santos and Simon, $1980 \mathrm{a}, \mathrm{b}$ ) indicate that responses to disturbance by 'opportunistic' species, as well as those of other species, can be quite variable and hence unpredictable. A number of species designated as opportunistic in the studies mentioned above were also important constituents of the Alewife Cove infauna (e.g. Streblospio benedicti, Polydora ligni and Capitella spp.). In the Cove, their responses ranged from total domination of initial and/or later stages to no settlement at all in habitats with extant ambient populations. Also, during certain times of the year most of the other species found in Alewife Cove exhibited settlement during initial stages with varying degrees of dominance (Zajac and Whitlatch, 1982).

These patterns suggest that marine infaunal succession may be best described by the tolerance and/or inhibition models, rather than the facilitation model, owing to variable settlement and density patterns during all stages of succession. However, studies by Rhoads et al. (1977) showed that habitat modification by species found during each successional stage may enhance settlement of subsequent species, suggesting that facilitative mechanisms of succession can occur in soft-bottom communities.

Since food resource levels may play an important role in infaunal recolonization (Grassle and Grassle, 1974; Thistle, 1981; Zajac and Whitlatch, 1982) the tolerance model may explain certain successional pat- terns. If the decline of initial colonizers is due to resource depletion and intra- and interspecific competition, then subsequent domination by a different suite of species may be due to more efficient exploitation of food and/or space resources. Competitive interactions for food (e.g. Whitlatch, 1980) and space (e.g. Peterson, 1977) have been documented, although the extent to which these interactions shape successional patterns has not been rigorously tested.

There is evidence that inhibition may also occur during infaunal successions. At SII in Alewife Cove, Streblospio benedicti and Polydora ligni dominated long-term experimental plots until winter mortality and/or reduced reproductive output reduced their numbers. During the following spring, large numbers of Capitella spp. settled into these plots, suggesting that monopolization of space (and/or food) by the two spionids inhibited the invasion of Capitella spp. during the initial stages of succession. At this time, local ambient densities of Capitella spp. were very high and increasing. Thus potential larval colonists were available. Richter and Sarnthien (1977) also found that for bivalves 'when a larval species arrives first it can occupy all niches and keep off all later arriving species'. However, until more experimental studies are conducted it will be difficult to assess the importance of facilitation, tolerance and inhibition mechanisms in these communities; we suggest that it would be of value to test mechanisms of soft-bottom infaunal succession along these theoretical lines.

Acknowledgements. We thank B. L. Welsh, F. C. Dobbs, J. Weinberg, V. Starczak, S. Malinowski and C. Katz for stimulating discussions and suggestions during the course of this study. R. DeGoursey and A. Lima provided valuable technical assistance, and we appreciate the constructive comments of 2 anonymous reviewers. This work was supported in part by grants from The State of Connecticut Department of Environmental Protection (to RBW) and The Sigma Xi Foundation (to RNZ). This is contribution No. 147 of the Marine Sciences Institute, University of Connecticut.

\section{LITERATURE CITED}

Boesch, D. F., Wass, M. L., Virnstein, R. W. (1976). The dynamics of estuarine benthic communities. In: Wiley, $M$. (ed.) Estuarine processes. Academic Press, New York, pp $177-196$

Connell, J. H., Slatyer, R. O. (1977). Mechanisms of succession in natural communities and their role in community stability and organization. Am. Nat. 111: 1119-1144

Dixon, W. J., Brown, M. B. (1979). Biomedical computer programs P-series, University of California Press, Berkeley

Drury, W. B., Nisbet, I. T. C. (1973). Succession. J. Arnold Arbor. 54: 331-368

Grassle, J. F., Grassle, J. P. (1974). Opportunistic life histories and genetic systems in marine benthic polychaetes. J. mar. Res. 32: 253-284 
Guerin, J. P., Masse, H. (1976). Experimental and methodological study of macrofaunal species recruitment in soft-bottoms. Tethys 8: 151-168

McCall, P. L. (1977). Community patterns and adaptive strategies of the infaunal benthos of Long Island Sound. J. mar Res. 35: 221-266

Odum, E. P. (1969). The strategy of ecosystem development. Science, N. Y. 164: 262-270

Paine, R. T., Levin, S. A. (1981). Intertidal landscapes: disturbances and the dynamics of pattern. Ecol. Monogr. 51: $145-178$

Pearson, T. H., Rosenberg, R. (1978). Macrobenthic succession in relation to organic enrichment and pollution of the marine environment. Oceanogr. mar. Biol. A. Rev. 16: 229-311

Peterson, C. H. (1977). Competitive organization of the softbottom macrobenthic communities of southern California lagoons. Mar. Biol. 43: 343-359

Reisch, D. J. (1961). A study of benthic fauna in a recently constructed boat harbor in southern California. Ecology 42: $84-91$

Rhoads, D. C., Aller, R. C., Goldhaber, M. B. (1977). The influence of colonizing benthos on physical properties and chemical diagenesis of the estuarine seafloor. In: Coull, B. C. (ed.) Ecology of the marine benthos. University of South Carolina Press, Columbia, pp. 113-138

Rhoads, D. C., McCall, P. L., Yingst, J. Y. (1978). Disturbance and production on the estuarine seafloor. Am. Sci. 66: 557-586

Richter, W., Sarnthien, M. (1977). Molluscan colonization of different sediments on submerged platforms in the west- ern Baltic Sea. In: Keegan, B. F., Ceidigh, P. O., Boaden, P. J. S. (eds.) Biology of benthic organisms. Pergamon Press, New York, pp. 531-539

Santos, S. L., Simon, J. L. (1980a). Marine soft-bottom community establishment following annual defaunation: larval or adult recruitment? Mar. Ecol. Prog. Ser. 2: 235-241

Santos, S. L., Simon, J. L. (1980b). Response of soft-bottom benthos to annual catastrophic disturbance in a south Florida estuary. Mar Ecol. Prog. Ser 3: 347-355

Thistle, D. (1981). Natural physical disturbances and communities of marine soft bottoms. Mar. Ecol. Prog. Ser. 6: $223-228$

Welsh, B. L., Herring, J. P., Read, L. M. (1978). The effects of reduced wetlands and storage basins on the stability of a small Connecticut estuary. In: Wiley, M. L. (ed.) Estuarine interactions. Academic Press, New York, pp. 381-401

Whitlatch, R. B. (1980). Patterns of resource utilization and coexistence in marine intertidal deposit-feeding communities. J. mar. Res. 38: 743-765

Whittaker, R. H., Levin, S. A. (1977). The role of mosaic phenomenon in natural communities. Theor. Pop. Biol. 12: $117-139$

Wolff, W. J., Sandee, A. J. J., de Wolf, L. (1977). The development of a benthic ecosystem. Hydrobiologia 52: 107-115

Zajac, R. N. (1981). Successional and ambient infaunal community dynamics in a New England estuary. Masters thesis, The University of Connecticut

Zajac, R. N, Whitlatch, R B. (1982). Responses of estuarine infauna to disturbance. I. Spatial and temporal variation of recolonization. Mar Ecol Prog Ser 10.1-14 